${ }^{3}$ Luft FC, Rankin LI, Bloch R, et al. Cardiovascular and humoral responses to extremes of sodium intake in normal black and white man. Circulation $1979 ; 60: 697-706$.

${ }^{4}$ Romoff MS, Kensch G, Campese VM, et al. Effect of sodium intake on plasma catecholamines in normal subjects. F Clin Endocrinol Metab $1979 ; 48: 26-31$.

${ }^{5}$ Burstyn P, Hornall D, Walchorn C. Sodium and potassium intake and blood pressure. $\mathrm{Br}$ Med f 1980 ;281 :537-9.

${ }^{6}$ Parijs J, Joosens JV, Van der Linden L, Verstrchan G, Amery AKPC. Moderate sodium restriction and diuretics in the treatment of hypertension. Am Heart $\mathcal{F} 1973 ; 85: 22-34$.

7 Morgan T, Gillies A, Morgan G, Adam W, Wilson M, Carney S. Hypertension treated by salt restriction. Lancet $1978 ; \mathrm{i}: 227-30$.

${ }^{8}$ Fujita T, Henry WL, Bartter FC, Lake RC, Delea CS. Factors influencing blood pressure in salt-sensitive patients with hypertension. $\mathrm{Am} \mathcal{F} \mathrm{Med}$ 1980;69:334-44.

9 Borst JG, Borst-de Geus A. Hypertension explained by Starling's theory of circulatory homeostasis. Lancet $1963 ; \mathrm{i}: 677-82$.

10 George CF, Lewis PJ, Petrie A. Clinical experience with use of ultrasound sphygmonanometer. Br Heart $\mathcal{f}$ 1975;37:804-7.

11 Roulston JE, MacGregor GA. Measurement of plasma renin activity by radioimmunoassay after prolonged cold storage. Clin Chim Acta 1978; $88: 45-8$.

12 James VHT, Wilson GA. Determination of aldosterone in biological fluids. In: Reid E, ed. Assay of drugs and other trace compounds in biological fluids. (Methodological developments in biochemistry. Vol 5.) Amsterdam: Elsevier/North Holland, 1976:149-58.

${ }^{13}$ Sullivan JM, Ratts TE, Taylor CJ, et al. Haemodynamic effects of dietary sodium in man. A preliminary report. Hypertension 1980;2:506-14.

14 Schechter PJ, Horwitz D, Henkin RI. Sodium chloride preference in essential hypertension. f $A M A 1973 ; 225: 1311-5$.

15 Schalekamp MADH, Schalekamp-Kuyken MPA, Birkenhager WH. Abnormal renal haemodynamics and renin suppression in hypertensive patients. Clin Sci 1970;38:101-10.

${ }_{16}$ Parfrey PS, Wright P, Ledingham PS. Prolonged isometric exercise Part 1: Effect on circulation and on renal excretion of sodium and potassium in mild essential hypertension. Hypertension $1981 ; 3: 182-7$.

17 Parfrey PS, Wright P, Ledingham PS. Prolonged isometric exercise. Part 2: Effect on circulation and on renal excretion of sodium and potassium in young males genetically predisposed to hypertension. Hypertension $1981 ; 3: 188-91$.

${ }^{18}$ Laragh JH, Baer L, Brunner HR, Buhler FR, Sealey BS, DarracottVaughan E. Renin, angiotensin and aldosterone system in pathogenesis and management of hypertensive vascular disease. $A m \mathcal{F}$ Med 1972 ; 52:633-52.

19 Campese VM, Myers MR, De Quattro V. Neurogenic factors in low renin essential hypertension. Am $\mathcal{F}$ Med 1980;69:83-91.

20 de Wardener HE, MacGregor GA. Dahl's hypothesis that a saluretic substance may be responsible for a sustained rise in arterial pressure: its possible role in essential hypertension. Kidney Int 1980;18:1-9.

${ }^{21}$ MacGregor GA, Fenton S, Alaghband-Zadeh J, Markandu ND, Roulston $\mathrm{JE}$, de Wardener $\mathrm{HE}$. An increase in a circulating inhibitor of $\mathrm{Na}^{+}-$ $\mathrm{K}^{+}$-ATPase-the link between salt intake and the development of essential hypertension. Clin Sci Mol Med (in press).

(Accepted 20 May 1981)

\title{
Poor sensitivity of multiple-gated blood-pool imaging in diagnosing left ventricular aneurysms
}

\author{
A P ALLEN, I PEART, D N TAYLOR, B R CONDON, B C OGILVIE, J W FRANK, H SUTTON, \\ D M ACKERY
}

\begin{abstract}
A study was carried out to determine the accuracy of multiple-gated blood-pool imaging in diagnosing left ventricular aneurysm. Fifteen patients with an aneurysm and 17 with left ventricular hypokinesia were studied by contrast ventriculography and multiple-gated blood-pool imaging. The results of blood-pool imaging were examined blind by five independent observers, the results of contrast ventriculography being used as the standard. The mean sensitivity of the procedure was $56 \%$, the specificity $61 \%$, and diagnostic accuracy $59 \%$.

These results indicate that contrast ventriculography remains the best method for diagnosing left ventricular aneurysms. Moreover, ventriculography provides additional information-for example, on wall thickness-not provided by multiple-gated blood-pool imaging.
\end{abstract}

\section{Introduction}

Ischaemic heart disease may be associated with global left ventricular hypokinesia (left ventricular "bag") or localised impairment of motion of the ventricular wall (an aneurysm). Differentiation between these two conditions is important as a patient with an aneurysm may benefit from cardiac surgery. Such differentiation cannot be done clinically, ${ }^{12}$ and at present contract ventriculography performed at cardiac catheterisation is the only method that will reliably distinguish the two conditions. This procedure has a small but important morbidity and mortality, so in recent years non-invasive radionuclide techniques have been examined as alternatives. It is important to determine whether radionuclide dynamic imaging is as successful as conventional contrast ventriculography in distinguishing between left ventricular aneurysms and left ventricular bags. This study was designed to evaluate the use of equilibrium radionuclide bloodpool imaging in making this distinction.

\section{Patients, methods, and results}

Thirty-two patients underwent contrast ventriculography in the right anterior oblique position and multiple-gated blood-pool imaging in both the right and left anterior oblique positions. Only patients with either an aneurysm (15) or a left ventricular bag (17) were included. In each case the result of multiple-gated blood-pool imaging was examined by five independent observers (with no knowledge of the result of contrast ventriculography) and classified as "aneurysm" or "not aneurysm." An aneurysm was defined as a region of akinesia or dyskinesia with good function in the remainder of the left ventricle. Diagnostic accuracy was defined as the percentage of patients correctly identified using contrast ventriculography as the standard. The table shows the results of the study for each observer.

A P ALLEN, MB, BS, senior house officer in nuclear medicine and cardiology I PEART, MB, MRCP, registrar in cardiology

D N TAYLOR, BTECH, PHD, senior
B R CONDON, BSC, MSC, physicist

B C OGILVIE, MRCP, FRCR, consultant radiologist

J W FRANK, MSC, FRCR, consultant radiologist

H SUTTON, MB, MS, senior registrar in nuclear medicine

D M ACKERY, MB, MSC, consultant in nuclear medicine 
Sensitivity, specificity, and diagnostic accuracy of multiple-gated blood-poo imaging for each of five observers

\begin{tabular}{lccc}
\hline Observer & $\begin{array}{c}\text { Sensitivity } \\
\left(0_{0}\right)\end{array}$ & $\begin{array}{c}\text { Specificity } \\
(0\end{array}$ & $\begin{array}{c}\text { Diagnostic accuracy } \\
\left(0_{0}\right)\end{array}$ \\
\hline 1 & 40 & 55 & 50 \\
2 & 58 & 62 & 59 \\
3 & 60 & 64 & 63 \\
4 & 60 & 59 & 59 \\
5 & 60 & 64 & 63 \\
\hline Mean & 56 & 61 & 59 \\
\hline
\end{tabular}

\section{Discussion}

These results show that multiple-gated blood-pool imaging achieved a low diagnostic accuracy. This was common to all five observers, even though only two diagnoses were possible, which ruled out the possibility of appreciable observer error. In one of two cases when all observers were in agreement their interpretation was incorrect.

These results may possibly reflect poor technique, but we think this unlikely since we paid scrupulous attention to optimisation of factors such as the choice of collimator, the orientation of the camera, counting statistics, subtraction of background, correction for arrhythmias, and matrix filtering. An analysis of regional wall motion using this radionuclide method $^{3}$ showed that motion of the basal segments of the left ventricle could not be assessed as accurately as motion of the distal segments.

We conclude that multiple-gated blood-pool imaging cannot detect accurately the presence of a left ventricular aneurysm. A possible reason for this is that in the right anterior oblique position the overlapping right ventricular activity may mimic or obscure good basal left ventricular contraction, the recognition of which is essential for the diagnosis of an aneurysm.
These disappointing results do not support the accuracy reported for detection of left ventricular aneurysm, which has been as high as $96 \%{ }^{*}$ The reason for this difference is not clear although patient selection and varying techniques may be partially responsible. One alternative technique measures the first pass of a bolus of activity through the ventricle using a multicrystal gamma camera. ${ }^{5}$ This delineates the left ventricle without right ventricular overlap. This imaging device, however, is not widely available. In the future tomographic techniques using conventional gamma cameras may help to overcome the problem of right ventricular overlap. At present contrast ventriculography remains the best method for diagnosing left ventricular aneurysms; it also provides additional information on wall thickness, loss of normal trabecular pattern, and the presence of thrombus. These features may help in the specific diagnosis. Our study shows that multiple-gated blood pool imaging should not be used to screen patients for contrast ventriculography.

\section{References}

${ }^{1}$ Rigo P, Murray M, Strauss HW, Pitt B. Scintiphotographic evaluation of patients with suspected left ventricular aneurysm. Circulation $1974 ; 50$ : 985-91.

2 Graber JD, Oakley CM, Pickering BN, Goodwin JF, Raphael NJ, Steiner RE. Ventricular aneurysm. An appraisal of diagnosis and surgical treatment. Br Heart $\mathcal{F} 1972 ; \mathbf{3 4}: 830-8$.

${ }^{3}$ Harris DNF, Taylor DN, Garvie, NW, Sharratt GP, Ackery DM, Conway $N$. Left ventricular segmental wall motion: a comparison between equilibrium radionuclide angiography and cineangiography. Nuclear Medicine Communications 1980;1:78-82.

4 Winzelberg GG, Strauss HW, Bingham JB, McKusick KA. Scintigraphic evaluation of left ventricular aneurysm. Am $\mathcal{F}$ Cardiol 1980;46:1138-43.

${ }^{5}$ Dymond DS, Jarritt PH, Britton KE, Spurrell RAJ. Detection of postinfarction left ventricular aneurysms by first-pass radionuclide ventriculography using a multicrystal gamma camera. Br Heart $\mathcal{f} 1979$;41 :68-78.

(Accepted 11 fune 1981)
A cusтom has long prevailed among phyficians, of prognofticating, as they call it, the patient's fate, or foretelling the iffue of the difeafe. Vanity no doubt introduced this practice, and ftill fupports it, in fpite of common fenfe and fafety of mankind. I have known a phyfician barbarous enough to boaft, that he pronounced more fentences than all his Majefty's judges. Would to God that fuch fentences were not often equally fatal! It may indeed be alleged, that the doctor does not declare his opinion before the patient. So much the worfe. A fenfible patient had better hear what the doctor fays, than learn it from the difconfolate looks, the watery eyes, and the broken whifpers of thofe about him. It feldom happens, when the doctor gives an unfavourable opinion, that it can be concealed from the patient. The very embarraffment which the friends and attendants fhew in difguifing what he has faid, is generally fufficient to difcover the truth.

KIND Heaven has, for the wifert ends, concealed from mortals their fate; and we do not fee what right any man has to announce the death of another, efpecially if fuch a declaration has a chance to kill him. Mankind are indeed very fond of prying into future events, and feldom fail to folicit the phyfician for his opinion. A doubtful anfwer, however, or one that may tend rather to encourage the hopes of the fick, is furely the moft fafe. This conduct could neither hurt the patient nor the phyfician. Nothing tends more to deftroy the credit of phyfic than thofe bold prognofticators, who, by the bye, are generally the moft ignorant of the faculty. The miltakes which daily happen in this way are fo many ftanding proofs of human vanity, and the weaknefs of fcience.

WE readily admit, that there are cafes where the phyfician ought to give intimation of the patient's danger to fome of his near connexions; though even this ought always to be done with the greateft caution: but it never can be neceffary in any cafe that the whole town and country fhould know, immediately after the doctor has made his firlt vifit, that he has no hopes of his patient's recovery. Perfons whofe impertinent curiofity leads them to queftion the phyfician with regard to the fate of his patient, certainly deferve no better than an evafive anfwer.

THE vanity of foretelling the fate of the fick is not peculiar to the faculty. Others follow their example, and thofe who think themfelves wifer than their neighbours often do much hurt in this way. Humanity furely calls upon every one to comfort the fick, and not to add to their affliction by alarming their fears. A friend, or even a phyfician, may often do more good by a mild and fympathizing behaviour than by medicine, and fhould never neglect to adminifter that greateft of all cordials, HOPE.

NEXT to milk, we would recommend good light bread. Bread may be given to a child as foon as it fhews an inclination to chew; and it may at all times be allowed as much plain bread as it will eat. The very chewing of bread will promote the cutting of the teeth, and the difcharge of Saliva, while, by mixing with the nurfe's milk in the Atomach, it will afford an excellent nourifhment. Children difcover an early inclination to chew whatever is put into their hands. Parents obferve the inclination, but generally miftake the object. Inftead of giving the child fomething which may at once exercife its gums and afford it nourifhment, they commonly put into its hands a piece of hard metal, or impenetrable coral. A cruft of bread is the beft gumftick. It not only anfwers the purpofe better than any thing elfe, but has the additional properties of nourifhing the child and carrying the faliva down to the ftomach, which is too valuable a liquor to be loft.

(Buchan's Domestic Medicine, i786.) 